\title{
Exploring Socio-Cultural Factors that Affect the Potential to Start a Business: In Case Indonesia University Students
}

\author{
Irfan Sophan Himawan ${ }^{1}$, Astri Dwi Andriani ${ }^{2}$, Herlina Herlina ${ }^{3}$ \\ \{Irfan.sophan@gmail.com ${ }^{1}$, astridwiandriani@gmail.com², lina.andiirawan@gmail.com $\left.{ }^{3}\right\}$ \\ Universiti Teknologi Mara, Malaysia ${ }^{1}$, Universitas Putra Indonesia, West Java, Indonesia ${ }^{2}$, \\ Universitas Mandiri, West Java, Indonesia ${ }^{3}$
}

\begin{abstract}
The results showed that the potential to open new businesses for students was significantly influenced by factors such as residential factors, family expectations, and community attitudes. It was found that the decision to pursue a career was strongly influenced by the family and society in general. It is hoped that there will be collaboration between universities, communities, and business practitioners to increase student interest so that they start opening businesses. The combination of theory and practice is very much needed in order to increase the capacity of human resources for regional and even national economic growth.
\end{abstract}

Keywords: Residential Factors; Family Expectation; Community Attitude; Potential to Start a Business

\section{Introduction}

Entrepreneurship is formulated and is expected to be the foundation of economic growth in a country, including business activities, decision making on risks, creating something new, and utilizing existing resources to innovate both from ideas, products, and even new services [1]. Also, potential to start business refers to dynamic and innovative changes in which entrepreneurs will respond to changes in the surrounding environment [2]. In developing countries such as Indonesia, it can be said that academics have a higher unemployment rate. For educated people, seeing entrepreneurship is a necessity, not an opportunity. So, they are encouraged to start a business and become self-employed [3].

So far, research has mostly focused on intention and knowledge. However, Temesgen (2020) found that entrepreneurship courses had a significant effect on students' entrepreneurial intentions, namely [4]: increasing students' knowledge, skills, and self-confidence to become entrepreneurs. The results of Katz's study (1992) show that family expectations and background influences influence students' potential to start business [5]. Furthermore, Peterman and Kennedy (2003) in their research suggest that the intention to start a new business becomes more positive with advice or suggestions from families for entrepreneurship [6]. According to Abebe and Angriawan (2011: 2), entrepreneurship among young and educated people is still lacking [7]. However, there is still little entrepreneurship research that links socio-cultural factors in society. Meanwhile, students are the foundation of the country's success. The novelty of this research is to explore the socio-cultural factors that will affect the 
potential to start a business which previously have not been studied in detail by previous researchers.

\section{Literature Review}

\subsection{Residential Factors}

Based on previous research, it shows that students who live in urban and rural areas have one common desire in the field of entrepreneurship, the difference is that students who are residents have higher personal control than students from rural residents. Students with urban backgrounds are more likely to become entrepreneurs or than those who live in rural areas. As the results of research from De Hoyos-Ruperto (2009) stated that the background of residence will greatly affect their mindset and attitude to take risks and ultimately affect their minds to learn to be entrepreneurs [8]. Empirical evidence, Maphosa (1998) describes that the development of entrepreneurship / entrepreneurial culture is influenced by residential and local socio-cultural factors [9] and the courage factor is also a supporter of entrepreneurial activities. Farrington et al. (2012) analyzed that ownership of a certain location/demography will support their intention to start a new business [10].

Based on the theoretical review and the empirical phenomena mentioned above, this study was designed using the following hypothesis:

Hypothesis 1: The respondent's residence has a significant effect on the potential of students to start a business.

\subsection{Family Expectation}

In the findings of Maphosa (1998), MacLelland explained that the development of an entrepreneurial character is closely related to the attitudes and behavior of parents. Parents expect their children to have high achievement and are expected and encouraged to be able to behave/act independently from an early age.[9] The entrepreneurial interaction that they build is the independence of interacting with peers and family which can be a support or even a failure (Kamaumaina 2006:15).[11] It is said by Maphosa (1998: 175) that the development of entrepreneurial personality is related to factors of independence, innovation, and risk taking which are obtained from the family environment.[9] The influence of family support can be very strong in developing business ideas for their children. So it is not surprising that for those whose families or parents are businessmen, their children will determine their choice to become entrepreneurs as well as their parents' work.

Based on research by Nanda and Sorensen (2009), family, friends, and relatives have a strong share or influence in their children's career choices because they are considered role models that can be emulated in real terms.[12] So based on the review above, it leads to the following hypothesis:

Hypothesis 2: Family expectation has a significant effect on the potential of students to start a business.

\subsection{Community Attitude}

Assumptions that develop in society with the existence of entrepreneurship make motivation for most of the people around them who have not been involved in entrepreneurial 
activities, let alone there are quite close relationships or contacts. Then there is a positive interaction about entrepreneurship so that it raises one's intention to become an entrepreneur. For example: the business activities of Chinese people who are supported by their families and relatives are recognized as role models for others around them.[13] Based on empirical evidence, Maphosa (1998: 175) states that community is a very important attitude/social factor whose influence is able to encourage or hinder entrepreneurial development activities.[9] Cultural attitudes are also one of the things that can contribute to entrepreneurial success and make people's motivation and mindset change to do business. Studies that have been conducted for a long time from the Czech Republic and Slovakia, people tend to have a negative attitude towards small entrepreneurs.[14] However, this is different from Mokry's (1998) study that local communities actually play an important role in the entrepreneurial development process.[15]

Furthermore, based on the study above, the following hypothesis is formulated:

Hypothesis 3: People's attitudes have a significant effect on the potential to open a business.

\subsection{Conceptual Framework}

Based on the theoretical and empirical studies above, the authors develop a conceptual framework as follows:

Regression model specification

$\mathrm{Y}=\mathrm{B} 0+\beta 1 \mathrm{X} 1+\beta 2 \mathrm{X} 2+\beta 1 \mathrm{X} 3+\beta 2 \mathrm{X} 4+\mathrm{e}$

\begin{tabular}{|c|c|c|c|}
\hline Whe & $=$ potential to start business & X3 & $=$ community attitude \\
\hline $\mathrm{X} 1$ & $=$ residential factors & $\beta$ & $=$ Beta coefficient \\
\hline $\mathrm{X} 2$ & $=$ family expectation & B0 & $=$ constant \\
\hline
\end{tabular}

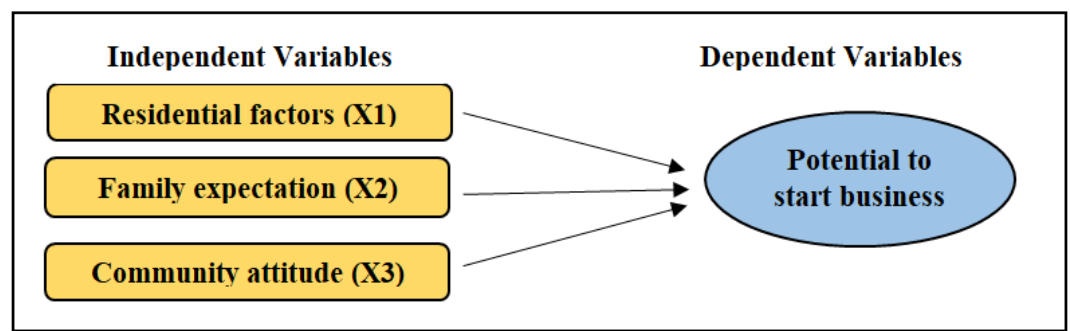

Fig. 1. Conceptual Framework

\section{Methodology}

This study uses a mixed research approach and research design using descriptive and explanatory. While the quantitative approach is used for statistical processing that will give results about how much influence factors such as residential factors, family expectations, and community attitudes have on the potential to open a business. And then the qualitative research approach is to describe each variable to what extent it contributes to the potential to 
open a business. And in this study also explained about the relationship between independent variables to determine the relationship.

\subsection{Sampling Procedure and Sample Size}

The data was obtained from the activities of distributing questionnaires in stages. The sampling technique is carried out thoroughly in the same opportunity so that it does not cause a sample gap. The total population of 18 classes consisting of 3 universities is 720 management education class students in odd semesters, namely semesters 3, 5, and 7 in 2021. So the sample obtained with a standard deviation of $5 \%$ is 257 respondents/students. The technique of distributing questionnaires is done online, namely by using the google form within the specified time. Furthermore, from the results of the questionnaire, the researcher guarantees that the data is confidential, accurate, and anonymous. The data is recorded accurately because every person who fills out the questionnaire, the data is directly entered into the researcher's file. Furthermore, the collected data were analyzed using correlation analysis and multiple linear regression.

\subsection{Measurements}

All questions were distributed to respondents after going through the validation and reliability process. Then each variable was measured on a 5-point Likert scale, ranging from '1' (strongly disagree) to '5' (strongly agree).

\section{Results and Discussion}

\subsection{Correlation Analysis}

In data processing used Pearson correlation coefficient analysis to determine whether there is a significant relationship between the independent and dependent variables. In Table 1 shows the correlation as said According to Cohen (1992), namely the interpretation of the range of correlation coefficients is as follows:[16] 0.3 to +0.3 is weak, 0.3 to 0.5 is moderate, 0.5 to 0.9 is strong, and 0.9 to 1 is very strong. Table 1 shows the results of Pearson's product moment correlation analysis that there is a strong positive significant relationship between the independent variable residents factors and the dependent variable potential to start a business on the correlation coefficient and sig. level $0.427(.000)$, the family expectation variable obtained $.359(.000)$, and community attitude $.668(.000)$. while the residence factor does not have a significant relationship with the dependent variable at a correlation coefficient of 0.003 and sig. level of $0.627(\mathrm{P}>0.05)$.

\begin{tabular}{|c|c|c|c|c|c|}
\hline & & $\begin{array}{l}\text { Residential } \\
\text { Factors }\end{array}$ & $\begin{array}{c}\text { Family } \\
\text { Expectation }\end{array}$ & $\begin{array}{c}\text { Community } \\
\text { Attitude }\end{array}$ & $\begin{array}{c}\text { Potential to } \\
\text { Start Business }\end{array}$ \\
\hline \multirow[t]{3}{*}{$\begin{array}{c}\text { Residential } \\
\text { Factors }\end{array}$} & $\begin{array}{c}\text { Pearson } \\
\text { correlation }\end{array}$ & 1 & .114 & -026 & -0.03 \\
\hline & Sig. (two-tailed) & & .156 & .153 & .627 \\
\hline & $N$ & 257 & 257 & 257 & 257 \\
\hline $\begin{array}{c}\text { Family } \\
\text { Expectation }\end{array}$ & $\begin{array}{l}\text { Pearson } \\
\text { correlation }\end{array}$ & .117 & 1 & .564 & 339 \\
\hline
\end{tabular}




\begin{tabular}{cccccc}
\hline & & $\begin{array}{c}\text { Residential } \\
\text { Factors }\end{array}$ & $\begin{array}{c}\text { Family } \\
\text { Expectation }\end{array}$ & $\begin{array}{c}\text { Community } \\
\text { Attitude }\end{array}$ & $\begin{array}{c}\text { Potential to } \\
\text { Start Business }\end{array}$ \\
\hline & Sig. (two-tailed) & .152 & & 000 & 000 \\
Community & $\boldsymbol{N}$ & 257 & 257 & 257 & 257 \\
Attitude & Pearson & .127 & 576 & 1 & 668 \\
& correlation & & & & \\
Sig. (two-tailed) & .142 & 000 & & 000 \\
$\begin{array}{c}\text { Potential to Start } \\
\text { Business }\end{array}$ & $\boldsymbol{N}$ & 257 & 257 & 257 & 257 \\
& Pearson & .0 .02 & .506 & .687 & 1 \\
& correlation & & & & \\
& Sig. (two-tailed) & 886 & .000 & .000 & 257 \\
\hline
\end{tabular}

Based on statistical processing, the overall results of correlation, histogram, and p-p plots show that there are no problems of multicollinearity, normality, and linearity in this study.

\subsection{Regression Analysis}

Based on the results of Table 2 above, the value of $\mathrm{R}$ square is 0.644 and the adjusted value of $\mathrm{R}$ square is 0.605 . This shows that $64.4 \%$ of the variation in the potential to start a business is explained by the determinants of community attitude in the study area. Also, the significance value of the $\mathrm{F}$ statistic shows a value of 0.000 , and is smaller than $p<0.05$, meaning that the model is quite significant and there is no problem with the fitness model in this study (Table 3 ).

Table 2. Regression analysis

\begin{tabular}{|c|c|c|c|c|c|c|c|c|c|}
\hline \multicolumn{10}{|c|}{ Model Summary } \\
\hline \multirow[t]{2}{*}{ Model } & \multirow[t]{2}{*}{$\mathbf{R}$} & \multirow{2}{*}{$\begin{array}{c}\mathbf{R} \\
\text { square }\end{array}$} & \multirow{2}{*}{$\begin{array}{l}\text { Adjusted } \\
\text { R square } \\
\end{array}$} & \multirow{2}{*}{$\begin{array}{l}\text { Std. error of } \\
\text { the estimate }\end{array}$} & \multicolumn{5}{|c|}{ Change statistics } \\
\hline & & & & & $\begin{array}{c}\text { R square } \\
\text { change }\end{array}$ & $\begin{array}{c}\mathbf{F} \\
\text { change }\end{array}$ & df1 & df2 & $\begin{array}{l}\text { Sig. F } \\
\text { change }\end{array}$ \\
\hline 1 & $.767^{\mathrm{a}}$ & .644 & .605 & 43.618 & .644 & 36.223 & 6 & 136 & .000 \\
\hline
\end{tabular}

\subsection{Model Equation}

Based on the regression analysis above, the results of the regression model equation are as follows:

$\mathrm{Y}=0: 693+(0) \mathrm{X} 1+(0.207) \mathrm{X} 2+(0.402) \mathrm{X} 3+(0.402)+\mathrm{e}$

Where $\mathrm{Y}=$ potential to start business

$\mathrm{X} 1=$ Residential factors

$\mathrm{X} 2 \quad=$ Family expectation

X3 = Community attitude

$\mathrm{E}=$ other factors not included in the study ( 0.05 random error) 
Table 3. Regression coefficients

\begin{tabular}{|c|c|c|c|c|c|c|}
\hline \multicolumn{2}{|r|}{ Model } & \multicolumn{2}{|c|}{$\begin{array}{l}\text { Unstandardized } \\
\text { Coefficients }\end{array}$} & \multirow{2}{*}{$\begin{array}{c}\begin{array}{c}\text { Standardized } \\
\text { Coefficients }\end{array} \\
\text { Beta }\end{array}$} & \multirow[t]{2}{*}{$\mathbf{t}$} & \multirow[t]{2}{*}{ Sig } \\
\hline & & B & Std. error & & & \\
\hline \multirow[t]{4}{*}{1} & Constant & .693 & .276 & & 2341 & .0 .10 \\
\hline & Residential factors & -0.60 & .047 & -.065 & -1.443 & .182 \\
\hline & Family expectation & .207 & .056 & .277 & 2.556 & .005 \\
\hline & Community attitude & .402 & .036 & .423 & 4.114 & .000 \\
\hline
\end{tabular}

The results of the regression analysis prove that family expectations have a significant positive effect on potential to start business at a standard beta value of 0.207 at $p=0.005$, community attitude has a significant positive effect on students' potential to start business at a standard beta value of .402 at $\mathrm{p}=0.000$, while residential factors does not have a positive effect on students' potential to start business at the standard beta value of -0.60 with a significance level of $0.0182(p>0.05)$. This clearly shows that people's attitudes are the most contributing variables or factors in this research study.

\subsection{Discussion}

In our country, Indonesia, the expectations of students to become entrepreneurs are still relatively moderate, this is because their family environment or parents are mostly civil servants or employees. Of the 257 respondents, most of them still expressed doubts about starting a business in earnest. They still want to have a permanent income from the government in the form of a salary. Based on the results of Pearson's product moment correlation analysis, it proves that there is a strong significant positive relationship between the independent variables, namely family expectations and community attitudes and the dependent variable is potential to start a business. Meanwhile, resident factors do not have a significant relationship with the dependent variable.

The $\mathrm{R}$ square value is 0.644 and the adjusted $\mathrm{R}$ square value is 0.605 ; This indicates that $64.4 \%$ of the variation in potential to start business is explained by socio-cultural factors in the study area, and the remaining $35.6 \%$ of variations in potential to start business are influenced by other variables not included in this study. Furthermore, the results of the two-way ANOVA test indicate that the fitness model in this study is quite good. the results of this regression analysis detect that, first, the resident factor has no significant effect on the dependent variable on sig. level of $0.0182(\mathrm{p}>0.05)$. These results contradict the results of research by Peterman and Kennedy (2003), Katz (1992), Nanda and Sorensen (2009), Maphosa (1998), and Farrington et al. (2012).

Hypothesis 1: resident factors have a significant effect on the potential of students to become entrepreneurs. Then reject hypothesis 1 and accept the null hypothesis.

Third, family expectation has a significant positive effect on students' potential to start business. Thus the results of this study support the results of previous studies.[12];[17];[18]

Hypothesis 2: family expectation has a significant effect on potential to start business. Then accept hypothesis 2 and reject the null hypothesis.

Finally, community attitude has a significant positive effect on potential to start business and is the most contributing factor to potential to start business. This is because the Indonesian people still uphold the culture of their respective regions who follow the instructions of their 
parents or their families in terms of job selection. So it is not surprising that the decisions of family groups, peer groups, and community judgments will determine their children's career choices. This finding is in line with the results of studies conducted by Maphosa (1998: 175), Swanson and Webster (1992) and Mokry (1988).

Hypothesis 3: Community attitude has a significant effect on potential to start business. So, the decision is to accept alternative hypothesis 4 and reject the null hypothesis.

In general, research results show that students expect an example/role model in the business world who has greater motivation, innovation, an active attitude to seek opportunities, risk-taking behavior, and independence. Family Expectations and community attitudes greatly affect students' intentions to become entrepreneurs as their job choice in the future. Students who tend to be interested in entrepreneurship are those who are encouraged by their parents and families to be able to live independently so that they are expected to be able to become entrepreneurs soon.

\section{Conclusion}

The main objective of this research is to explore the potential to start a business and its socio-cultural determinants: in the case of students in the Department of Management at three (3) universities in Indonesia. The parameters used in this study are independent variables (resident factors, family expectations, and community attitudes as well as potential to start business as the dependent variable. The results of research using regression and correlation show good results on the statistical relationship of each independent variable with the dependent variable). After going through an analysis of all parameters, it was found that family expectations and community attitudes had a significant effect on the potential to start a business, while the resident factor had no significant positive effect. residence.

\section{Recommendations}

The researcher suggests to the local government to start trying to provide supporting facilities for people who intend to open a business or develop their business. Likewise, universities are expected to have activities that implement theory into real practice so that later students will not be awkward or do not hesitate to open a business armed with the knowledge and experience they have gained during college.

\section{Acknowledgement}

All costs for the publication of this article are borne by the authors.

\section{Conflicts of Interest}

The authors declare no conflict of interest.

\section{References}


[2] Lucky, E. "Nurturing entrepreneurship development in the 21st Century: the practical approaches," International Journal of Humanities and Social Science, vol. 1, no. 9, pp. 219-227, 2011.

[3] Schaumburg-Müller, H., Jeppesen, S., \& Langevang, T. "Entrepreneurship development in Africa.," In report from a workshop. Working Paper Series, 2010.

[4] Temesgen. "Socio-demographic Determinants of Entrepreneurial Intention in Case of University Graduation Students".

[5] Katz, J. "A Psychological Cognitive Model of Employment Status Choice," Entrepreneurship Theory and Practice, vol. 17, no. 1, pp. 29-37, 1992.

[6] Peterman, N.E., and J. Kennedy. "Entreprise education: Influencing Student's perceptions of Entrepreneurship," Entrepreneurship Theory and Practice, vol. 28, no. 2, pp. 129-144, 2003.

[7] Abebe M.A., and A. Anggriawan. "The Internationalization of Small and Mediumsized enterprise (SMEs): A Multi-level Integrative framework," International Journal of Entrepreneurship and Innovation Management, vol. 13, no. 3-4, pp. 377-397, 2011.

[8] De Hoyos-Ruperto, M. "Toward an Understanding for Entrepreneurship Environtment: The Case of Puerto Rico," 2009. [Online]. Available: https://www.researchgate.net/publication/266497633.

[9] Maphosa, F. "Towards the Sociology of Zimbabwean Indigenous Entrepreneurship," Zambezia, vol. 25, no. 2, pp. 173-190, 1998.

[10] Farrington, S.M., et al. "Entrepreneurial Intentions: Demographic Perspective of South African Business Students," South African Journal of Business Management, vol. 43, no. 3, pp. 41-49, 2012.

[11] Kamaumaina, R. "Stimulating Youth Entrepreneurship in Kenya," Available on: http://weatherhead.case.edu/edm/archieve/files/concept/Maina\%20Concept\%20Paper\%206-21-06.pdf., 2006.

[12] Nanda, R., \& J. Sorensen. "Workplace Peers and Entrepreneurship," Harvard Business School Entrepreneurial Management. Working Paper, pp. 08-051, 10 March 2009.

[13] Kao, J. "The Wordwide Web of Chinese Business," Harvard Business Review, vol. 71, no. 2, pp. 24-36, 1993.

[14] Swanson, D., \& Webster, L. "Private Sector Manufacturing in Czech and Slovak Federal Republic: A Survey of Firms," Industry and Energy Department Working Paper, Industy Series Working Paper No. 68, 1992.

[15] Mokry, B. "Entrepreneurship and Public Policy: Can Government Stimulate Business Startups?," in Quorum Books, 1988.

[16] Cohen J., "Statistical Power Analysis," Current Direction in Psychological Science, vol. 1, no. 3, pp. 98-101, 1992.

[17] Shapero A. "The Entrepreneurial Event," in The Environtment for Entrepreneurship, Lexington, Mass. Lexington Books, 1984.

[18] Scott, M., \& Twomey, D. "The Lon-term supply of entrepreneurs: Student's Career Aspirations in Relation to Entrepreneurship," Journal of Small Business Management, vol. 26 , no. 4, pp. 5-13, 1988. 